\title{
SODOBNE RAZVOJNE SMERI POLKMETOV NA PRIMERU VOKLEGA
}

Erik Logar, dipl. geograf in zgodovinar

Vrtna pot 6,Voglje, SI-4208 Šenčur

e-mail: logarerik@gmail.com

Izvirni znanstveni članek

COBISS 1.01

DOI: $10.4312 /$ dela.39.4.67-86

\section{Izvleček}

Prispevek skuša ovrednotiti sodobne razvojne smeri polkmetov v Voklem. Ti imajo veliko zaslug pri ohranjanju drobne posesti in prehranske samooskrbe. Od skupno 128 gospodinjstev v naselju je 13 polkmečkih, 15 kmečkih in 100 nekmečkih. Ker polkmetje združujejo kmetijsko dejavnost in zaposlitev izven kmetije, so povezovalni člen med različnimi socialnimi skupinami. Zaradi družbenogospodarskih sprememb so se v zadnjih dveh desetletjih izoblikovale tri razvojne smeri polkmetov: polkmetje kot kategorija $\mathrm{v}$ izumiranju, kot polkmetje - podjetniki ter samooskrbno-tržni polkmetje.

Ključne besede: polkmet, mešana kmetija, podeželje, Voklo, Kranjsko-Sorško polje, socialna geografija

\section{CONTEMPORARY DEVELOPMENTAL TENDENCIES OF PART-TIME FARMERS:THE CASE STUDY OF VOKLO}

\begin{abstract}
The article focuses on the contemporary role of part-time farmers, their structure and value in the rural settlement of Voklo. They have been an important factor in the maintenance of small agricultural holdings and in their own food subsistence. Out of 128 households, there are 15 farm, 13 part-time farm and 100 non-farm households. Part-time farmers in Voklo combine their agricultural activities with their off-farm employment, and therefore act as a direct link between different social groups. Due to socio-economic changes in the last two decades, three contemporary roles of part-time farmers occurred: part-time farmers as endangered category, entrepreneurial part-time farmers and self-subsistence part-time farmers.
\end{abstract}

Key words: part-time farmer, part-time farm, rural area, Slovenia, Voklo, Kranjsko-Sorško polje, social geography 


\section{UVOD}

V zadnjem stoletju se podeželje močno spreminja. Pred drugo svetovno vojno se je večina prebivalstva $\mathrm{v}$ slovenskih vaseh ukvarjala s kmetijsko dejavnostjo, vendar sta hiter razvoj človeške družbe in razmah globalnega gospodarstva ob koncu 20. in v začetku 21. st. podeželskim naseljem naglo spremenila videz in funkcije. Še mnogo bolj korenite spremembe so opazne v načinu življenja in miselnosti ljudi. Na podeželju se je kljub modernizaciji in številnim inovacijam delno ohranila zapuščina preteklosti; s tem ni mišljena le arhitekturna dediščina, temveč tudi način življenja in navade sodobnega človeka. Zaradi sprememb vsakdanjega življenja (dnevne prakse) se je spremenilo tudi dojemanje podeželskega prostora (Woods, 2005). Kot prehodni sloj med čistimi kmeti in delavci so polkmetje pokazatelj nekdanjega, svojevrstnega načina preživetja ali pa mogoče nosilci novih teženj na podeželju postindustrijske družbe.

V slovenski strokovni javnosti je problematika polkmetov vse manj aktualna. Razlog za to ni njena raziskovalna nezanimivost, ampak predvsem negotove gospodarske razmere za kmetovanje na manjših, z vidika socio-ekonomske klasifikacije, mešanih kmetijah. Zaradi družbenogospodarskih sprememb so polkmetje v zadnjih dveh desetletjih postali zelo 'ogrožena vrsta', maloštevilen sloj med podeželani. Njihova dvojna zaposlitev je na razvojnem razpotju, saj se je v socializmu polkmečka struktura mnogo lažje ohranjala kot v današnji družbenogospodarski ureditvi. Temelj obstanka in razvoja sodobnih polkmetov je uskladitev njihovega načina življenja z zahtevami sodobnega sveta, sicer bo z osredotočanjem intenzivnega tržnega kmetovanja na velikih kmetijah na podeželju prišlo do obsežnih prostorskih, družbenih in gospodarskih sprememb.

Zadnja preučitev polkmečke strukture je bila v slovenski geografiji opravljena pred več kot 20 leti. Ker se sodobne raziskave mešanih kmetij večinoma posvečajo njihovim finančnim in administrativnim težavam, nam je preučitev polkmečke strukture - vsakdanjega življenja in problemov polkmetov - predstavljala velik izziv, saj smo morali samostojno oblikovati način raziskovanja in predstavitve rezultatov. S prispevkom želimo ovrednotiti sodobno vlogo polkmetov v Voklem ter opozoriti na njihove razvojne probleme in posledice pri (ne)uspešnem prestrukturiranju njihove kmetijske dejavnosti.

Prvi del prispevka prinaša kratek teoretsko-metodološki pogled na problematiko polkmetov z vidika terminologije in dejavnikov, ki so vplivali na značilnosti sodobnega življenja polkmetov v Voklem. V drugem delu bodo podane glavne ugotovitve, oblikovane na osnovi uporabljenih raziskovalnih metod, in ovrednotene razvojne smeri polkmetov v Voklem.

\section{METODE RAZISKOVANJA}

Problematiko polkmetov smo preučevali s kombinacijo različnih metodoloških pristopov, kar nam omogoča (dokaj) celosten pogled na njihov razvoj in vlogo v podeželski skupnosti. Čeprav sta pojav in razvoj polkmetov v strokovni literaturi dobro raziskana, pojem pa je opredelilo več avtorjev, ga statistični in kartografski viri ne zaznavajo kot posebno prebivalstveno kategorijo. Zaradi njihove 'razpetosti' med več gospodarskih dejavnosti je raziskavo potrebno, poleg statističnih in prostorskih analiz, nujno kombinirati tudi s kvalitativno 
metodo. Le dosledno kombinirana uporaba metod (analiza obstoječih virov in literature, zbiranje in obdelava statističnih podatkov, prikaz prostorskega razvoja, metoda intervjuja in terensko delo) omogoča sledenje zastavljenim ciljem raziskave. S polkmeti je bilo v aprilu 2012 opravljenih osem intervjujev, v katerih so odgovarjali na vprašanja o nekdanjih in sedanjih izzivih, priložnostih in problemih združevanja kmetovanja ter zaposlitve v nekmetijski dejavnosti. Glavne ugotovitve raziskave smo prikazali tudi z grafično metodo.

\section{OBMOČJE PREUČEVANJA}

Poleg sosednjih Vogelj je Voklo edino naselje z lego v osredju Kranjskega polja; ostala naselja so zaradi vršajev in vodotokov razmeščena po njegovih robnih območjih (Melik, 1959). Razpoložljivost vodnih virov in kmetijskih zemljišč sta bila glavna pogoja za stalno naselitev prebivalstva. V obliki kolonizacijskega tipa vasi so v 12. st. na obeh straneh glavne vaške poti med lokvijo in cerkvijo nastale prve kmetije. Okoliško obdelovalno zemljo so razdelili v proge, ki so se ohranile do danes (Ilešič, 1933). Naselje je poimenovano po lokvi, ki je bila njegovim prebivalcem glavni vir pitne vode. Vanjo se je nekdaj stekal potok, ki teče od Olševka mimo Srednje vasi in ponikne pred Šenčurjem (Koblar, 1892), njegov tok pa je danes močno spremenjen in Voklega ne doseže več.

Razpoložljivost kakovostnih kmetijskih zemljišč je temelj močne tradicije kmetovanja, ki se v naselju ohranja iz generacije v generacijo. Kmetijska zemljišča okoli Voklega so po obstoječi kategorizaciji kmetijskih zemljišč uvrščena $v$ 1. razred, torej »... z najširšo možnostjo kmetijske rabe, ki se kaže v možnosti gojenja vseh kmetijskih rastlin v Sloveniji, če lega tal omogoča uporabo vseh vrst kmetijske mehanizacije.« (Opis območij ..., 2007, str. 4). Skrbno obdelane njivske površine običajno z visokimi hektarskimi donosi poplačajo kmetovo delo in finančne vložke.

Prometna dostopnost do naselja se je precej izboljšala leta 1985, ko so v njegovi neposredni bližini zgradili avtocesto. Vse več dnevnih migrantov od tedaj odhaja v Ljubljano. Tudi lega v sosedstvu največjega slovenskega letališča na Brniku pozitivno vpliva na razvoj zaposlitvenih možnosti ter novih poslovnih stikov in priložnosti. Polkmetje in kmetje iz Voklega imajo za košnjo sena v najemu velike travniške površine ob letališki stezi. Dostopnost do zaposlitvenih središč polkmetu omogoča redno zaposlitev v nekmetijski dejavnosti, saj mu vožnja na delovno mesto ne predstavlja velikega časovnega in denarnega stroška.

Naselju sta se v zadnjih sto letih lokacija in dostopnost torej močno izboljšali. Obe lastnosti plemenitita kakovost bivalnega okolja in privlačnost bivanja v naselju. Voklo postaja 'magnet' za priseljevanje nekmečkega prebivalstva z zaposlitvijo zunaj naselja, ki ceni življenje na podeželju in stik z naravo.

Bližina avtoceste in letališča imata tudi negativne okoljske vplive: hrup, izpušne pline ter konflikte pri rabi najboljših kmetijskih zemljišč. Kmetijsko dejavnost v Voklem je odvzem rodovitnih zemljišč (za potrebe izgradnje raznovrstne infrastrukture) precej prizadel.

»Vzeli so nam zemljo. Čez sredo parcele, nekdaj velike en hektar, so zgradili avtocesto. To je res negativno. Danes imamo na obeh delih avtoceste majhni njivi, vse skupaj ni nič.» (ženska, 59 let) 
Zaradi podružnične enote Osnovne šole Šenčur, trgovine z živili in izpostave Kmetijske zadruge Cerklje uvrščamo Voklo v središčno naselje prve stopnje (Benkovič Krašovec, 2006). S sosednjimi Vogljami, kjer so storitvene in gostinske dejavnosti nekoliko bolj razvite, tvorita funkcionalno naselbinsko celoto. Sedež občine, župnije in osnovne šole je v Šenčurju. Občinsko središče krepi zaposlitvene zmogljivosti zaradi nove poslovne cone, saj ima vizijo razviti se v najbolj podjetniško občino na Gorenjskem (Razvojni program občine Šenčur ..., 2004). Nizka stopnja središčnosti ter pomanjkanje delovnih mest v Voklem spodbujata polkmete k dnevni migraciji in $\mathrm{k}$ preusmeritvi iz kmetijstva $\mathrm{v}$ druge, donosnejše gospodarske panoge. Zaradi hitrih in dobrih cestnih povezav je cilj večine dnevnih migrantov Kranj.

\section{OPREDELITEV POJMA 'POLKMET' INTEORETSKA IZHODIŠČA}

\section{I.Terminološke nejasnosti}

Beseda 'polkmet' označuje človeka »... v rednem delovnem razmerju v nekmetijski dejavnosti, ki na lastnem zemljišču, zemljišču družinskih članov ali najetem zemljišču kmetuje popoldne, konec tedna in med letnim dopustom. « (Geografski terminološki slovar, 2005, str. 298), oziroma osebo »..., ki je redno zaposlena v nekmetijski dejavnosti in ponavadi dnevno odhaja na delo $\mathrm{v}$ zaposlitveno središče, obenem pa popoldan, konec tedna in $\mathrm{v}$ času letnega dopusta dela na lastni zemlji, zemlji svojih staršev ali na najeti zemlji.« (Kladnik, 1999, str. 171). Besedi 'polkmet' sta pomensko zelo blizu tudi zastarela izraza 'polproletarec' in 'kmet-delavec'.

Dvojna aktivnost je osnova vsem opredelitvam, ki skušajo strnjeno in pregledno zaobjeti temeljne značilnosti polkmečke strukture. Množica različnih pojmov in opredelitev v strokovni literaturi odseva labilnost in variabilnost socialne skupine polkmetov, saj je preučevana problematika tesno povezana $\mathrm{z}$ velikimi prostorskimi in socialnimi spremembami kmečkih gospodarstev po drugi svetovni vojni (Klemenčič, V., 1968). Večina obstoječe terminologije je zaradi družbenogospodarskega razvoja pomensko zastarela in vsebinsko neuporabna za opisovanje sodobnih procesov na podeželju, zato se postopno spreminja iz geografske v ‘zgodovinsko' - gre za ‘zorenje’ pojma. Kljub zastarelosti je ohranitev in preučevanje pojmov o polkmečki strukturi izjemnega pomena za poznavanje njenega razvoja in spreminjanja skozi čas (Kladnik, 2012; Razpotnik Visković, 2012).

Eden ključnih vidikov naše raziskave je bilo tudi opazovanje 'rojevanja in umiranja' geografskih pojavov in z njimi povezanih pojmov. S preučitvijo časovno-pomenskega razvoja različnih opredelitev lahko posredno izluščimo tudi prevladujoče procese in vplive geografskega prostora v času nastanka pojma. Npr.: opredelitev kajžarjev je najbolje ustrezala dejanskemu stanju od njihovega nastanka kot posebnega sloja prebivalstva zaradi delitve hub v zgodnjem novem veku (Blaznik, 1966) pa vse do konca druge svetovne vojne, ko zaradi velikih družbenih in gospodarskih sprememb o njih ne moremo več govoriti. Pojem sodi danes v zgodovinsko domeno - te socialne skupine ni več, vendar je kljub temu pomembno izhodišče za preučitev sodobnih polkmetov. Kajžarji so do danes ostali nekakšna 
prispodoba, nemalokrat celo slabšalno-posmehljiva oznaka za ljudi, ki morajo iskati dodatno zaposlitev zunaj kmetije zaradi premalo kmetijske zemlje (Kladnik, 2012). Pojmi, ki so danes že del zgodovinske terminologije, kažejo, da je polkmečka struktura na slovenskem podeželju navzoča že dlje časa in se spreminja skupaj z njim.

Ob zbiranju in medsebojni primerjavi literature se je v istem časovnem obdobju pojavilo več različnih, vendar med seboj sorodnih opredelitev polkmečke strukture, npr. polkmet, polproletarec in kmet-delavec v drugi polovici 20. st. Čeprav so si v jedru - to je dvojni zaposlitvi - povsem enotne, so se raznoliki pogledi in mnenja oblikovali predvsem zaradi raziskovanja strokovnjakov iz več znanstvenih področij, kot so geografija, ruralna sociologija, ekonomija, zgodovina, agronomija in etnologija. Večinoma so novi pojmi nastali spontano: raziskovalci so jih oblikovali in opredelili tako, da so najbolje služili potrebam njihovih raziskav, čeprav so sorodne opredelitve polkmečke strukture v drugih vedah že obstajale. Zato kljub veliki pomenski podobnosti med pojmi ne moremo govoriti o sopomenkah, saj vsakega izmed njih običajno uporabljajo le v eni stroki. Pestra množica opredelitev polkmeta povzroča tudi zmedo pri tipologiji in poimenovanju gospodinjstev, v katerih ti ljudje živijo (Kladnik, 2012; Razpotnik Visković, 2012).

Pojem 'polkmet' so po drugi svetovni vojni oblikovali geografi pod vplivom nemške smeri socialne geografije (Klemenčič, V., 2012; Kladnik, 2012). Iz svoje strokovne literature so ga uspešno razširili tudi v terminologijo sorodnih ved, saj geografsko pojmovanje polkmeta v nasprotju z ostalimi, ožjimi opredelitvami, poudarja širše učinke dvojne zaposlitve na pokrajino in družbo. Ohlapna opredelitev pojma glede združevanja kmetovanja in dela v nekmetijski dejavnosti plemeniti njegovo uporabno vrednost, saj dopušča poljubne kombinacije s kmetijsko dejavnostjo: ne samo z delom v industriji (kot npr. pojma polproletarec in kmet-delavec), temveč tudi s podjetništvom in obrtjo.

V literaturi ni enotnega mnenja, kdaj lahko gospodinjstvo opredelimo za polkmečko. V tem prispevku opredeljujemo kot gospodinjstva polkmetov tista, kjer se vsaj eden izmed odraslih članov gospodinjstva zaposli izven domače kmetije (Klemenčič, V., 1968), medtem ko nekateri drugi avtorji v gospodinjstva polkmetov uvrščajo le taka, kjer je izven kmetije redno zaposlen tudi gospodar kmetije (Krašovec, 1965; cv: Klemenčič, M. M., 1974).

Polkmečko strukturo opisuje precej pojmov, ki izkazujejo medsebojno pomensko podobnost in hkrati raznolikost. Zaradi mnogoterih prostorskih učinkov polkmečke strukture so se pri opredelitvah izoblikovali raznoliki zorni koti, ki kažejo na izrazito interdisciplinarnost področja raziskovanja. Neenakost opredelitev kaže na notranjo nehomogenost polkmečke strukture, ki se kaže v precejšnjih odstopanjih glede odnosa polkmetov do njihove kmetije in zaposlitve ter pri razmerjih med dohodki od kmetije in zaposlitve v nekmetijskih dejavnostih.

\subsection{Polkmetje kot predmet socialne geografije}

Na podlagi različnih kriterijev prebivalci naselbinske skupnosti medsebojno tvorijo številne socialne skupine. Najpogosteje uvrščamo med navedene kriterije način življenja, navade, delo, vrsto in višino dohodka, verske in politične opredelitve. Ker so medčloveški odnosi in mišljenje posameznikov v vsaki skupnosti nenehno podvrženi dinamičnim spremembam v prostoru, se število in velikost socialnih skupin v družbi neprestano spreminjata (Ruppert in 
sod., 1981, str. 159). Razumevanje odnosa socialne skupine do prostora in njenega vedênja v njem je bistveno za opredelitev procesov v pokrajini. Prostor je vzrok spreminjanja socialnih skupin in hkrati tudi poligon njihovih prostorskih učinkov (Klemenčič, V., 2012).

Socialna geografija preučuje prostorsko organiziranje socialnih skupin in celotne družbe. Še posebej jo zanima součinkovanje med socialnimi skupinami in procesi v pokrajini. Vsak raziskovalec lahko samostojno opredeli kriterije za oblikovanje socialnih skupin kot metodološki koncept raziskovanja. Celoten vpliv skupnosti na pokrajino lahko razložimo le s holističnim načinom preučevanja, vendar ob tem ne smemo zanemariti vloge posameznih socialnih skupin in njihovih svojevrstnih prostorskih učinkov. Ker nas zanimajo tudi medsebojne povezave in učinkovanje med socialnimi skupinami, smo holistični pristop k raziskovanju nadgradili s konceptom sistemske teorije. Polkmetje kot socialna skupina so glavni predmet našega preučevanja.

Z nastankom polkmečke strukture so se oblikovale nove socialne skupine, ki so zaradi iskanja dodatnega zaslužka izven domače kmetije postopno spremenile tradicionalno strukturo agrarne skupnosti. Manjša odvisnost teh socialnih skupin od kmetijske dejavnosti je povzročala posebne prostorske učinke, ki so se sprva kazali v vse bolj ekstenzivno obdelanih njivskih površinah, po drugi svetovni vojni pa zaradi industrializacije tudi v prenehanju kmetijske dejavnosti in oddajanju kmetijske zemlje v najem drugim kmetom.

Voklo je bilo kljub zametkom socialne skupine polkmetov pred drugo svetovno vojno še vedno izrazito kmečko naselje, saj je prevladovala kmetijska dejavnost. Naselbinska skupnost je bila dokaj zaprta in samozadostna, meja med mestnim in podeželskim načinom življenja pa je bila povsem jasna, čeprav so se stiki z mestnimi naselji, predvsem Kranjem, redno ohranjali (prodaja na tržnici, upravno središče). Vaška skupnost je bila razslojena na gruntarje, kajžarje in bajtarje, vendar so bile medsebojne premoženjske razlike mnogo manjše kot danes: večini prebivalcev je kmetovanje bolj ali manj neposredno predstavljalo način preživetja.

Dnevne migracije so po drugi svetovni vojni postale običajen del vsakdana. Na vasi se je uveljavljena oblika preživetja začela spreminjati, saj so se možnosti za zaposlitev izven kmetijske dejavnosti izjemno povečale. To je povzročilo oblikovanje novih socialnih skupin: delavcev in polkmetov, ki so večinoma v vasi že odraščali in so imeli tradicijo obdelovanja zemlje privzgojeno od staršev. Novozgrajene 'delavske' hiše so vedno obdane z vrtom, ki je pri avtohtonem, čeprav nekmečkem prebivalstvu, pokazatelj navezanosti na zemljo. Vaška skupnost se je vse bolj odpirala novostim, kot so elektrifikacija, gradnja vodovoda in kanalizacije. Polkmetje so ohranili kmetijsko dejavnost na majhnih kmetijah in s tem nekoliko upočasnili proces deagrarizacije. Ker niso živeli le od kmetijske dejavnosti, so bili manj odvisni od naravnih razmer.

Socialne skupine so na podeželju nemalokrat v medsebojnih konfliktih (Woods, 2005); skupina polkmetov je celo soočena z vprašanjem lastnega obstanka. Socialna skupina čistih, velikih kmetov želi od polkmetov kupiti ali vsaj najeti kmetijsko zemljo, saj si s tem zagotovi višji dohodek od kmetijske dejavnosti. Delodajalci, ki polkmete zaposlujejo izven kmetije, od njih zahtevajo vse večjo časovno prilagodljivost, daljši delovni čas in višjo izobrazbo. Socialna skupina potencialnih kupcev pridelkov želi za nizko ceno dobiti najkakovostnejše pridelke. Znotraj polkmečke strukture so ob vsem tem namesto medsebojne pomoči in sodelovanja pogosto spori ter pomanjkanje komunikacije. Socialna skupina polkmetov se je zato znašla 
na razpotju: spremeniti morajo način svojega življenja in dela ali pa se prepustiti procesom sprememb in se vključiti v nove, sodobnim razmeram ustreznejše socialne skupine.

Večina literature pojmuje polkmečko strukturo kot izrazito prehodno socialno in gospodarsko kategorijo, ki je posledica industrijske dobe in naj bi se ob prenosu gospodarjenja kmetije na mlajše generacije razkrojila skupaj z drobno kmetijsko proizvodnjo (Klemenčič, V., 1968). Malokdo pa opozarja na njeno stalno prisotnost na podeželju in aktivno dinamično vlogo pri njegovem razvoju (Klemenčič, M. M., 1974). S pomočjo polkmečke strukture se tudi danes na majhnih kmečkih gospodarstvih v razvitih postindustrijskih državah ohranja in razvija kmetijska dejavnost. Čiste kmetije ob prenosu gospodarjenja na potomce pogosto postanejo mešane, saj se mlada generacija zaradi visoke izobrazbe, dobro plačanih služb in večje finančne varnosti gospodinjstva pogosto ni povsem pripravljena odreči svoji redni zaposlitvi.

Slika 1: Lokacija preučevanih kmetij*v Voklem in razporeditev njihovih kmetijskih zemljišč Figure 1: The location of studied farms and the distribution of their utilized agricultural land

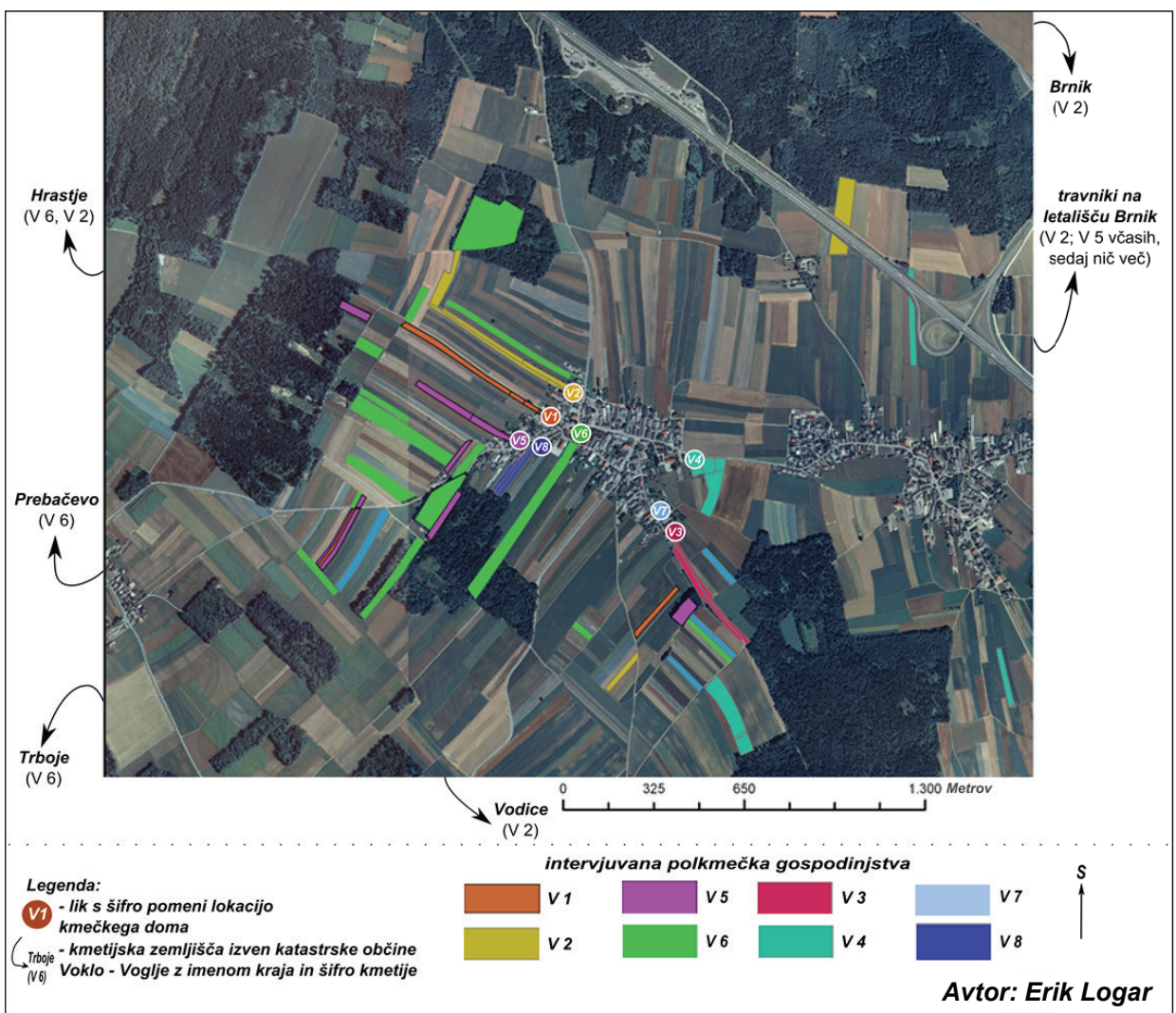

Vir/Source: ortofoto posnetek, GURS, 2012

* Kmetije, ki so bile vključene v raziskavo, smo zaradi varovanja osebnih podatkov namesto hišnega imena ali priimka poimenovali s sistemom šifer (prim. tudi preglednico 3). 


\section{GEOGRAFSKE ZNAČILNOSTI SODOBNE POLKMEČKE STRUKTUREVVOKLEM}

Vloga polkmetov kot socialne skupine na podeželju se je v postindustrijski dobi zelo spremenila (npr. zaradi vnovične uvedbe tržnega sistema, kmetijske politike in gospodarskega razvoja). Spremembe $v$ temeljnih elementih polkmečke strukture so povzročile nastanek nove prostorske podobe in pojmovanja polkmečke identitete. V industrijski dobi je kmetijska dejavnost polkmetov veliko pripomogla $\mathrm{k}$ ohranitvi tradicionalne podobe kulturne pokrajine. S kmetovanjem so omejili moč deagrarizacije ter preprečili, da bi večina kmetijskih zemljišč $\mathrm{v}$ naselju prešla $\mathrm{v}$ posest maloštevilnih velikih kmetov. Polkmetje so večinoma ohranili primarni namen kmečkih stavb in upočasnili spreminjanje fiziognomije naselja, vendar so nemalokrat stavbe povsem obnovili in celo postavili nove hleve in hiše. Kljub naši raziskavi še vedno ostaja nerazrešena dilema glede vpliva polkmetov na upočasnjevanje ali pospeševanje sprememb fiziognomije naselja.

\section{Slika 2: Rast števila prebivalcev $v$ Voklem}

Figure 2: Population growth in Voklo

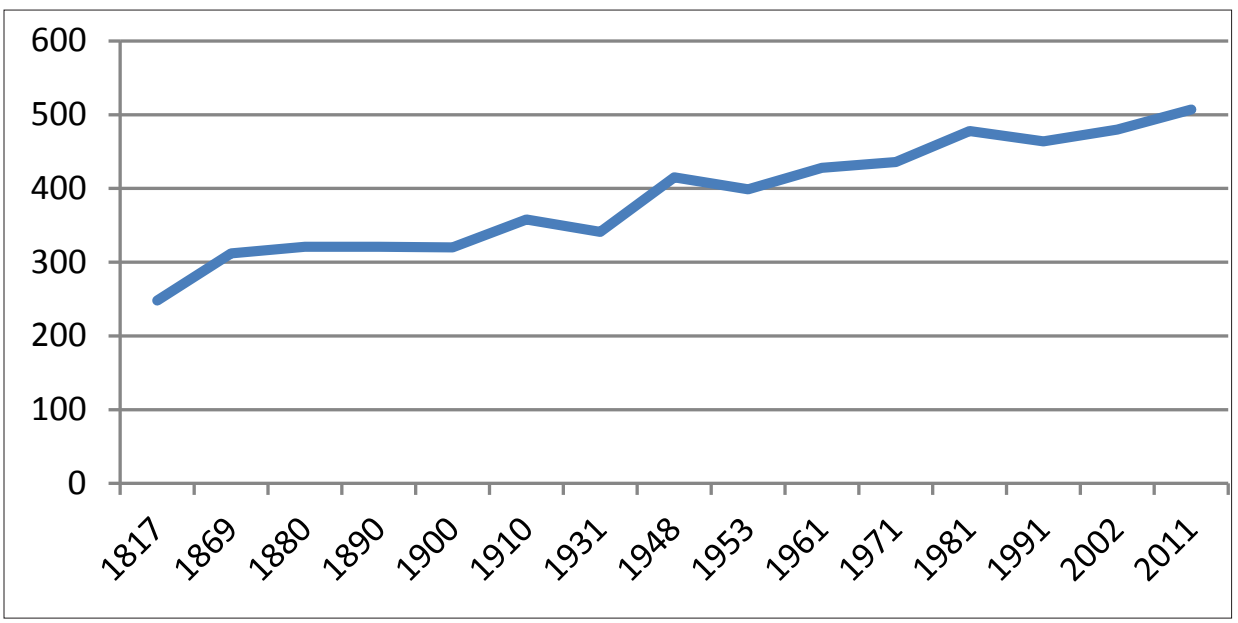

Vira/Sources: Rogelj, 2006; SURS, 2012

Zbrani in obdelani statistični podatki kažejo na upadanje števila kmečkega prebivalstva v Voklem. Čeprav število prebivalcev v naselju raste, se delež zaposlenih v primarnem sektorju po drugi svetovni vojni vztrajno zmanjšuje. Skupno število kmetijskih gospodarstev (od kmetov in polkmetov) se je v Voklem ustalilo na približno 30, kar smo ugotovili na osnovi vsakoletnega števila oddanih zbirnih vlog za pridobitev kmetijskih subvencij (Golc, 2012) in popisnih podatkov kmetijskih gospodarstev za leti 2000 in 2010. 
Slika 3: Deleži zaposlenih po gospodarskih sektorjih v popisnih letih v Voklem

Figure 3: Percentage of employees by economic sectors in Voklo

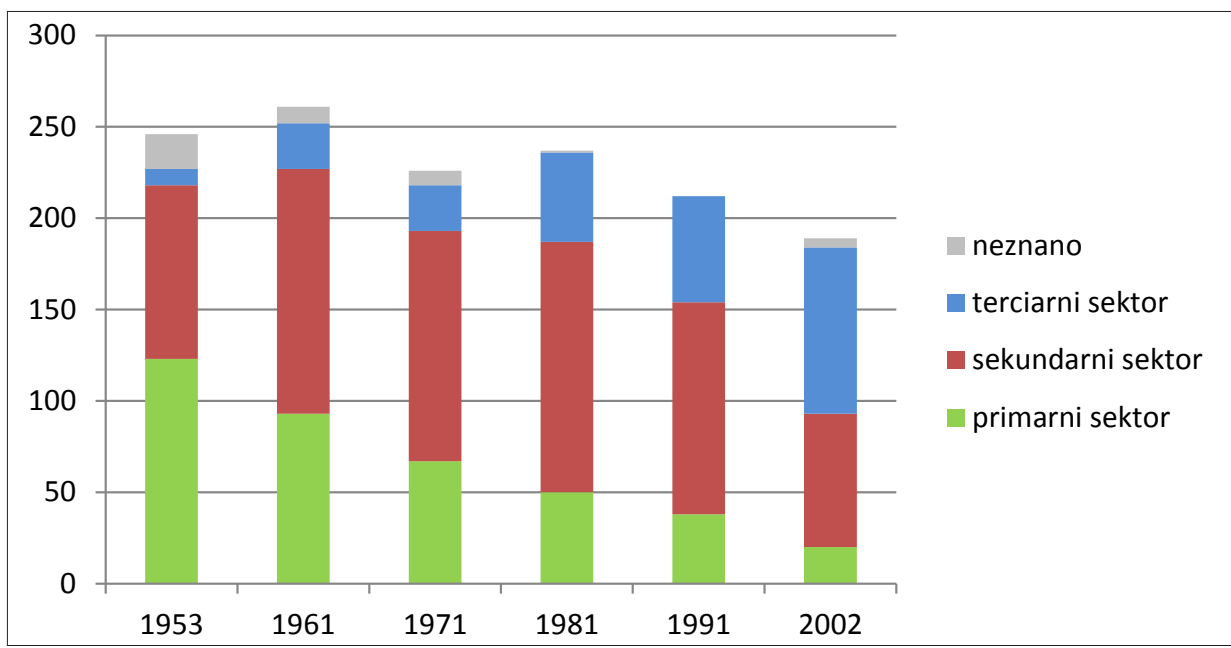

Viri/Sources: Prebivalstvo LR Slovenije ..., 1954; Popis stanovništva 1961..., 1965; Popis stanovništva i stanova 1971, 1974; Popis prebivalstva, ..., 1984; Popis prebivalstva ..., 1994; Popis 2002, 2012

Preglednica 1: Izbrani podatki iz popisov kmetijskih gospodarstev za leti 2000 in 2010 Table 1: Selected data from agricultural censuses of 2000 and 2010

\begin{tabular}{|l|c|c|c|c|}
\hline Kazalnik & $\begin{array}{c}\text { Število kmetijskih } \\
\text { gospodarstev } \\
\text { (2000) }\end{array}$ & $\begin{array}{c}\text { Številska } \\
\text { vrednost } \\
\text { kazalnika }\end{array}$ & $\begin{array}{c}\text { Stevilo kmetijskih } \\
\text { gospodarstev } \\
\text { (2010) }\end{array}$ & $\begin{array}{c}\text { Številska } \\
\text { vrednost } \\
\text { kazalnika }\end{array}$ \\
\hline Polnovredne delovne moči (PDM) & 32 & 47 & 31 & 48 \\
\hline Govedo & 27 & 517 & 18 & 461 \\
\hline Lastni dvoosni traktorji & 31 & 75 & 29 & 75 \\
\hline Lastni traktorski plugi & 31 & 31 & 27 & 27 \\
\hline Lastne kosilnice & 30 & 30 & 16 & 16 \\
\hline Lastne motorne žage & 29 & 34 & 19 & 26 \\
\hline Posek lesa (m³) & 28 & 549 & 20 & 709 \\
\hline $\begin{array}{l}\text { Kmetijska zemljišča v uporabi } \\
\text { (KZU) (ha) }\end{array}$ & 32 & 245 & 31 & 275 \\
\hline Njive (ha) & 32 & 193 & 31 & 231 \\
\hline Trajni travniki in pašniki (ha) & 30 & 49 & 19 & 43 \\
\hline Trajni nasadi (ha) & 29 & 2 & 5 & 1 \\
\hline
\end{tabular}

Vira/Sources: Popis kmetijskih gospodarstev 2000, 2002; Popis kmetijstva 2010, 2012 
Zelo podobno stanje je pokazala tudi analiza, ki smo jo pripravili na podlagi terenskega ugotavljanja dejavnosti in vrste dohodkov gospodinjstev v naselju. Rezultate smo predstavili $v$ grafičnem modelu, kjer smo kmečka in nekmečka gospodinjstva razporedili v dve množici, v njun presek pa smo zaradi dvojne zaposlitve uvrstili gospodinjstva polkmetov. Na podlagi statističnih analiz, intervjujev in terenskega opazovanja smo pri gospodinjstvih, ki so v zadnjih desetih letih spremenila vir dohodka, s puščicami v grafičnem modelu prikazali prehod med opredeljenimi tipi gospodinjstev po dejavnosti (npr.: 'kmečka' gospodinjstva so postala 'polkmečka', 'polkmečka' pa zaradi opustitve kmetovanja 'nekmečka').

Slika 4: Gospodinjstva v Voklem po številu članov in viru dohodka

Figure 4: Households in Voklo by the number of family members and the source of income

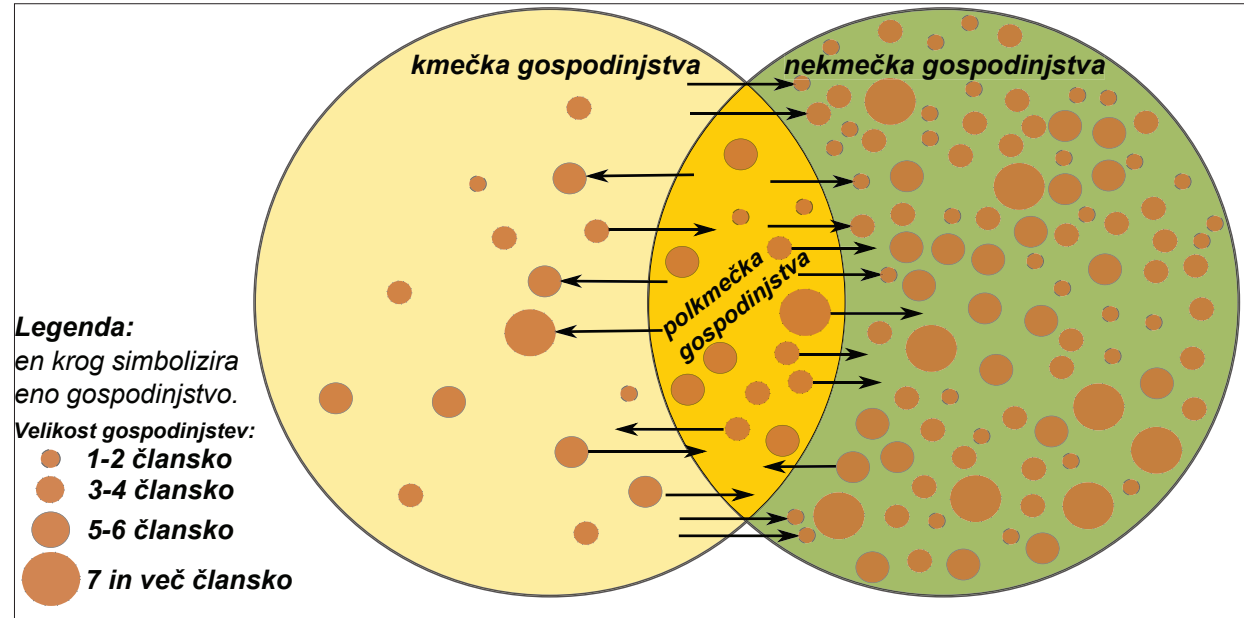

Avtor: Erik Logar

Vir/Source: Logar, 2012, 37

Kriterij za klasifikacijo:

- kmečko gospodinjstvo: izključni vir dohodka gospodinjstva predstavlja kmetijska dejavnost;

- polkmečko gospodinjstvo: dohodek gospodinjstva prihaja od nekmetijske in kmetijske dejavnosti;

- nekmečko gospodinjstvo: izključni vir dohodka gospodinjstva je nekmetijska dejavnost.

Sliki 4 in 5 smo izdelali na podlagi statističnih podatkov, intervjujev in terenskega dela. Glede na prevladujočo smer prehoda smo ugotovili (slika 4), da gospodinjstva v Voklem intenzivno opuščajo kmetijsko dejavnost, še posebej je to očitno pri polkmetih in na manjših čistih kmetijah. Tri kmečka gospodinjstva so se v zadnjem desetletju 
Slika 5: Prostorska razporeditev tipov gospodinjstev, središčnih funkcij in podjetij v Voklem Figure 5: Spatial distribution of the household types, central functions and enterprises in Voklo

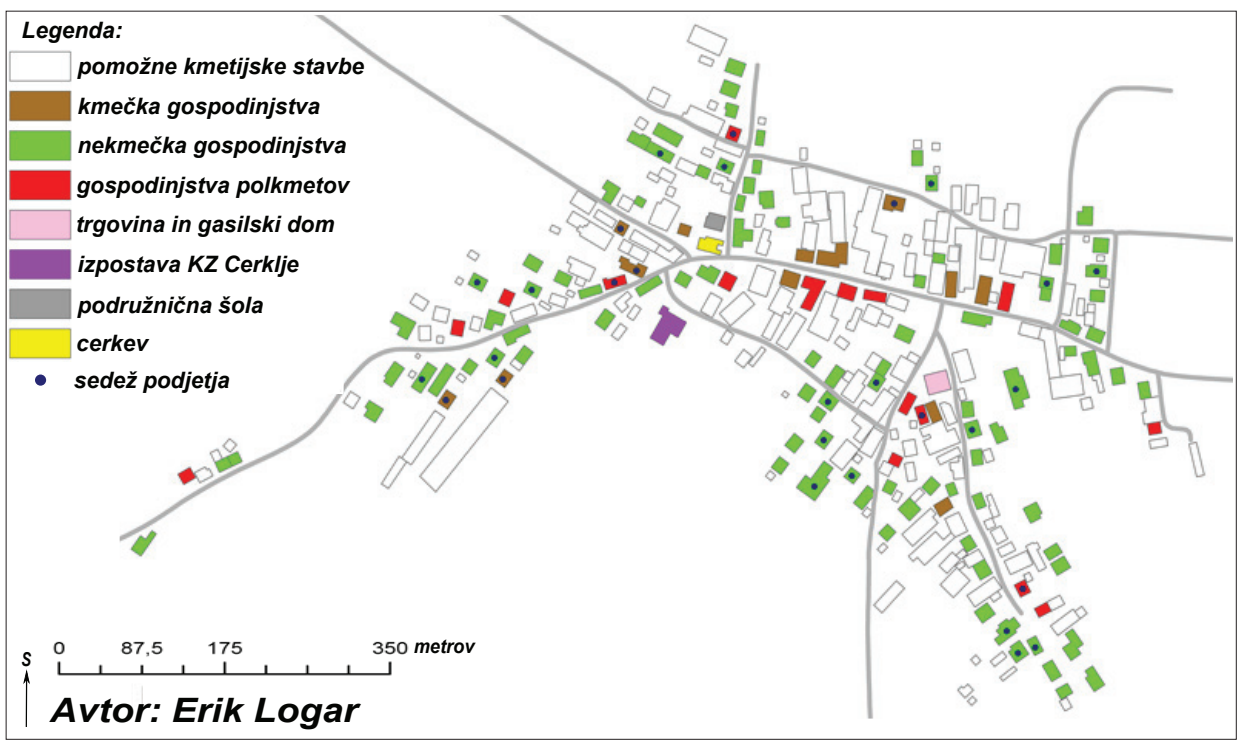

Vir podlage/Source: Kataster stavb, 2012

spremenila v polkmečka, sedem polkmečkih in štiri kmečka gospodinjstva pa so postala nekmečka. V Voklem je bilo v času našega popisa 13 polkmečkih, 15 kmečkih in 100 nekmečkih gospodinjstev. Zgolj troje gospodinjstev se je v zadnjih desetih letih, predvsem zaradi izgube zaposlitve izven kmetije ali predčasne upokojitve, spremenilo iz polkmečkega $v$ kmečki tip. Načrtna preusmeritev celotnega gospodinjstva zgolj v kmetijsko dejavnost je pri polkmetih zelo redka; s tem bi bili vezani le na en vir dohodka, kar znižuje finančno varnost njihovih gospodinjstev. Čeprav imajo čisti kmetje danes pogosto višje dohodke kot polkmetje, so povsem odvisni od pogosto nestanovitnega in nepredvidljivega trga kmetijskih pridelkov. Na proces deagrarizacije so opozorili tudi nekateri intervjuvanci.

»Vsako leto veliko kmetij propade; proizvodnja se povečuje, število kmetij pa upada.« (ženska, 40 let)

»Če bodo odkupne cene tako nizke, stroški pa tako visoki, bo vse skupaj vzel hudič. Morda bodo ostali samo močni kmetje, manjši pa ne bodo obstali.« (ženska, 47 let)

Za razumevanje različnih razvojnih smeri polkmetov moramo najprej spoznati posamezne elemente polkmečke strukture in ovrednotiti njihov vpliv na polkmečko strukturo 


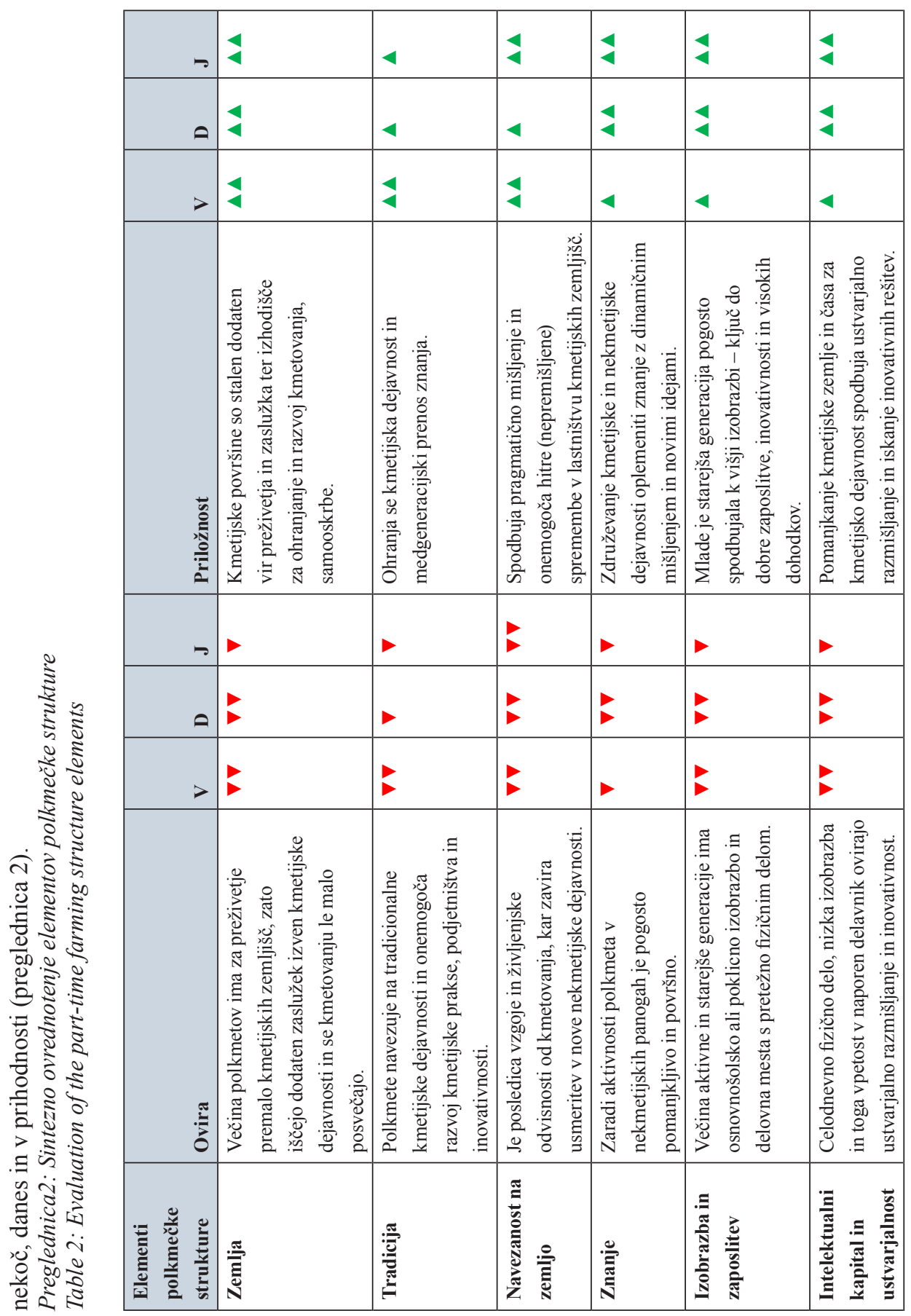




\begin{tabular}{|c|c|c|c|c|c|c|}
\hline 4 & 4 & 4 & 4 & 4 & 4 & 4 \\
\hline 4 & 4 & 4 & 4 & 4 & 4 & 4 \\
\hline 4 & 4 & 4 & 4 & 4 & 4 & 4 \\
\hline 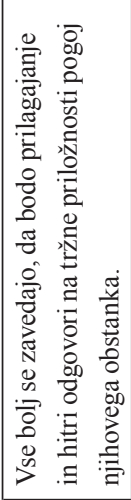 & 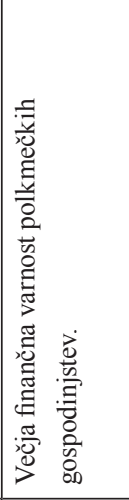 & 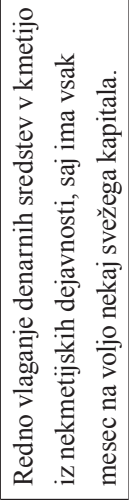 & 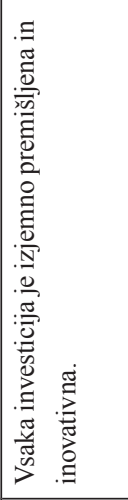 & 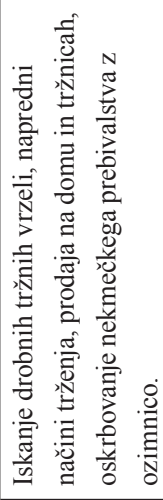 & 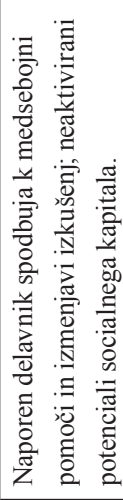 & 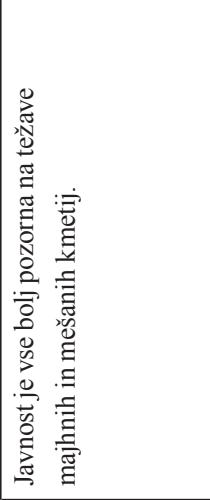 \\
\hline$b$ & 1 & 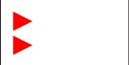 & 1 & 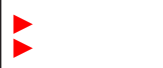 & 1 & 1 \\
\hline 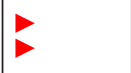 & 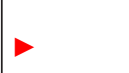 & 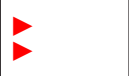 & $b$ & $b$ & 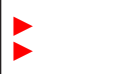 & 1 \\
\hline$b$ & 1 & 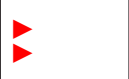 & 1 & 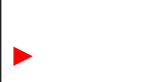 & 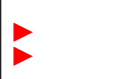 & 1 \\
\hline 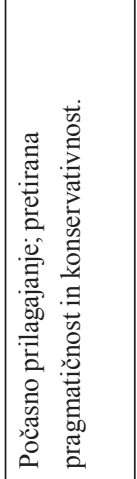 & 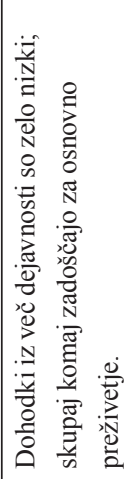 & 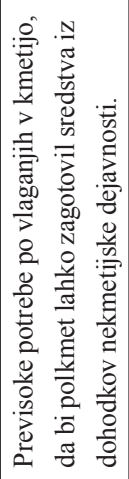 & 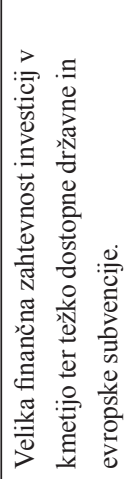 & 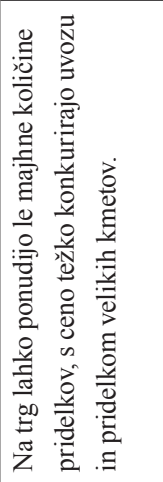 & 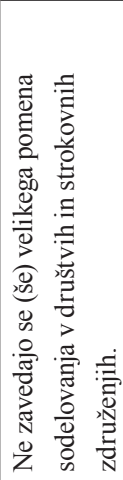 & 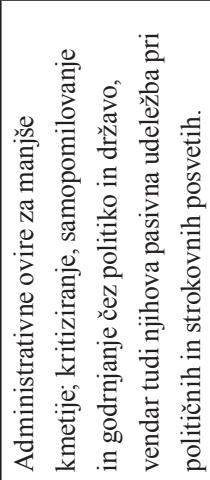 \\
\hline 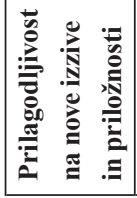 & 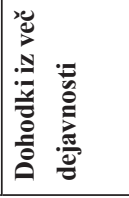 & 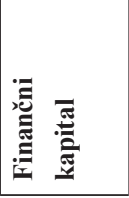 & 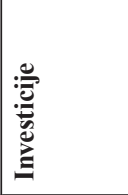 & 莺 & 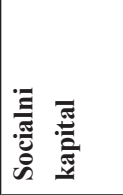 & 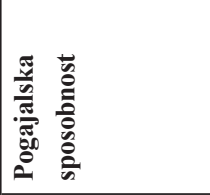 \\
\hline
\end{tabular}




\section{SODOBNE RAZVOJNE SMERI POLKMETOV}

Pripadniki socialne skupine polkmečke strukture, ki jih najustrezneje označuje izraz 'polkmet', so večinoma rojeni v obdobju med obema svetovnima vojnama; zelo malo je polkmetov, rojenih po drugi svetovni vojni. Ker te generacije prehajajo v tretje življenjsko obdobje, so se polkmetje znašli na razvojnem razpotju: če se ne bodo soočili s svojim položajem in ovrednotili lastnih razvojnih potencialov, se dvojna zaposlitev v njihovem gospodinjstvu ne bo obdržala. Tisti, ki svoje kmetije v Voklem že uspešno preusmerjajo v skladu s konceptom 'sodobno dopolnjene majhnosti' (Potočnik Slavič, 2010), to je na način, ki dopušča tudi povezovanje in usklajevanje $\mathrm{z}$ redno zaposlitvijo, so se prenehali soočati s krizo kmetovanja in njegove nedobičkonosnosti.

Vsaka od kmetij polkmetov, ki so bile vključene v našo raziskavo, ima svojevrstno vizijo in načrte za prihodnost, vendar se v splošnem kažejo tri glavne razvojne smeri polkmetov. Izoblikovale so se pod vplivom več dejavnikov, eden bolj odločujočih je starostno-generacijska sestava gospodinjstev (klasifikacijo gospodinjstev smo povzeli po Klemenčič, Lampič, Potočnik Slavič, 2008). V sledečem opisu razvojnih smeri polkmetov bomo s poskusom tipizacije polkmečkih gospodinjstev prikazali njihove glavne dosedanje in potencialne razvojne smeri.

\section{I. Polkmet kot kategorija v izumiranju}

Polkmetje tega tipa se dolgoročno ne bodo več ukvarjali z dvojno zaposlitvijo, saj živijo:

- V gospodinjstvih brez otrok, kjer so vsi člani starejši od 50 let;

- $\quad$ gospodinjstvih z otroci, ki so starejši od 35 let, ti pa so brez potomcev.

Odsotnost mlade generacije odseva v pretirani navezanosti na tradicionalne kmetijske panoge, pomanjkanju inovativnosti in podjetniškega duha. Njihova kmečka gospodarstva so avtarkična (Klemenčič, M. M., 1970). V kmetijo zaradi negotove prihodnosti ne vlagajo veliko, temveč se raje močno navežejo na svojo zaposlitev izven kmetije, ki jim zagotavlja redne dohodke. Pri polkmetih kot izumirajoči kategoriji je kmetijska dejavnost običajno v zadnjem stadiju pred opustitvijo. V rokah večjih, pogosto čistih kmetov, se zaradi tega začno kopičiti kmetijska zemljišča. Razvoj tega tipa polkmeta lahko prepreči le navzočnost mlade generacije v gospodinjstvu, četudi imajo redno zaposlitev in jih kmetijska dejavnost ne zanima. Mladi, ki so bili vzgojeni v polkmečkih gospodinjstvih, praviloma imajo vizijo in ohranijo lastništvo kmetije ter na njej nadaljujejo življenje.

\subsection{Samooskrbno-tržni polkmet}

Mesečni zaslužek od zaposlitve izven kmetije je pri tem tipu polkmeta še vedno najpomembnejši dohodek v gospodinjstvu. Z dvojno zaposlitvijo bo kljub temu nadaljeval še naprej. Tak tip polkmeta se razvije:

- v gospodinjstvih s srednjo generacijo, kjer so otroci stari od 25 do 35 let;

- v mladih gospodinjstvih, kjer so vsi člani mlajši od 35 let. 
Dvojna zaposlitev je pri tem tipu pojmovana kot vrednota in način življenja. S kmetijsko dejavnostjo se tak polkmet ukvarja le v prostem času, predvsem zaradi sprostitve in pridelave hrane zase, obenem pa ohranja kulturno pokrajino in tradicijo prednikov. $\mathrm{V}$ kmetijo iz mesečnega zaslužka vlaga zelo malo ali nič, saj skuša z dohodki od kmetijske dejavnosti pokriti stroške investicij v kmetijo. Ta tip polkmeta je sicer tržno naravnan in skuša prodajati svoje pridelke, vendar to ni njegov glavni cilj.

\section{3. Polkmet - podjetnik}

To so polkmetje, ki dvojno zaposlitev vidijo kot priložnost in izhodišče za razvoj podjetništva. Inovativne ideje oblikujejo iz izkušenj, pridobljenih tako na kmetiji kot tudi na delovnem mestu. Na svojo kmetijo gledajo kot podjetniki na podjetje: odpraviti skušajo njene pomanjkljivosti in slabosti ter se nenehno prilagajajo povpraševanju trga in na njem iščejo tržne vrzeli. Ugodno okolje za razvoj takega tipa polkmetov, kjer prihaja do velike medgeneracijske izmenjave izkušenj in znanj, so predvsem:

- trigeneracijska gospodinjstva;

- gospodinjstva s srednjo in mlado generacijo.

Preglednica 3: Lastnosti posameznih tipov polkmetov

Table 3: Characteristics of individual part-time farmer types

\begin{tabular}{|c|c|c|c|}
\hline Lastnosti & $\begin{array}{l}\text { Polkmet kot kategorija } \\
\text { v izumiranju }\end{array}$ & $\begin{array}{l}\text { Samooskrbno-tržni } \\
\text { polkmet }\end{array}$ & Polkmet-podjetnik \\
\hline $\begin{array}{l}\text { Gospodarska } \\
\text { usmerjenost kmetije }\end{array}$ & $\begin{array}{l}\text { Tradicionalne kmetijske } \\
\text { panoge }\end{array}$ & $\begin{array}{l}\text { Kombiniranje kmetijskih } \\
\text { panog, za samooskrbo }\end{array}$ & $\begin{array}{l}\text { Dobičkonosne kmetijske } \\
\text { panoge, ki odgovarjajo } \\
\text { povpraševanju na trgu }\end{array}$ \\
\hline Vitalnost gospodinjstva & $\begin{array}{l}\text { Ostarelo gospodinjstvo, } \\
\text { odsotnost mlade } \\
\text { generacije }\end{array}$ & $\begin{array}{l}\text { Mlada generacija je že } \\
\text { prešla v zrelo generacijo }\end{array}$ & $\begin{array}{l}\text { Mlada generacija } \\
\text { je sestavni del } \\
\text { gospodinjstva }\end{array}$ \\
\hline Vir dohodka & $\begin{array}{l}\text { Večinoma dohodki } \\
\text { od zaposlitve izven } \\
\text { kmetijske dejavnosti, } \\
\text { večinoma socialni } \\
\text { transferji }\end{array}$ & $\begin{array}{l}\text { Dohodki od zaposlitve } \\
\text { izven kmetijske } \\
\text { dejavnosti, priložnostno } \\
\text { od prodaje pridelkov }\end{array}$ & $\begin{array}{l}\text { Od kmetijske dejavnosti } \\
\text { skušajo iztržiti čim več }\end{array}$ \\
\hline $\begin{array}{l}\text { Odnos do kmetijske } \\
\text { dejavnosti }\end{array}$ & $\begin{array}{l}\text { Konservativnost, strah } \\
\text { pred novostmi }\end{array}$ & $\begin{array}{l}\text { Preživljanje prostega } \\
\text { časa in priložnostni } \\
\text { zaslužek }\end{array}$ & Podjetnost, inovativnost \\
\hline $\begin{array}{l}\text { Primeri intervjuvanih } \\
\text { gospodinjstev }\end{array}$ & V 5 & $\mathrm{~V} 2, \mathrm{~V} 3, \mathrm{~V} 7$ & V $1, \mathrm{~V} 4, \mathrm{~V} 6, \mathrm{~V} 8$ \\
\hline
\end{tabular}




\section{RAZISKOVALNE DILEME IN POMISLEKI}

Čeprav so polkmetje po opredelitvi vezani na dvojno zaposlitev, se je morala večina od njih pod vplivom tržnega gospodarstva odločiti le za eno izmed obeh dejavnosti, ki jim predstavlja glavni vir dohodka. Nekdaj je bila v polkmečkih gospodinjstvih večina odraslih članov redno zaposlenih, popoldne pa so se doma vsi ukvarjali s kmetijsko dejavnostjo. V gospodinjstvih sodobnih polkmetov se del članov, ki je zaposlen izven kmetije, le malo posveča kmetijski dejavnosti zaradi stresnih in časovno zahtevnih delovnih mest; vse več časa namenjajo rekreaciji in oddihu. Podobno velja tudi za preostale člane gospodinjstva, ki se ukvarjajo s kmetovanjem - za dodatne nekmetijske dejavnosti jim ne ostane veliko časa. Zaradi specializacije v kmetijstvu in na delovnem mestu prihaja do zatona dvojne zaposlitve. Sodobni način življenja polkmetom preprosto ne dopušča, da bi še vedno enakovredno združevali zaposlitev izven kmetije in kmetovanje.

Čeprav so se intervjuvanci strinjali, da njihov način življenja in zaslužka v osnovi ustreza geografskemu strokovnemu izrazu 'polkmet', se z njim ni nihče poistovetil; v vsakodnevnem pogovornem jeziku se ta beseda ni nikoli uveljavila. Njihova osebna identiteta večinoma temelji na podobi kmečkega človeka, ki ima poleg kmetije dodatno redno zaposlitev. Najbolj soroden pogled osnovni opredelitvi polkmetov imajo čisti kmetje, ki zaradi nevoščljivosti, danes pa tudi zaradi vse večje ošabnosti, na polkmete gledajo kot 'dvoživke', ki se kmetiji posvečajo zgolj polovičarsko.

Združevanje dohodkov iz različnih dejavnosti je po novi socio-ekonomski tipizaciji kmetij najboljša sodobna strategija obstanka in napredka kmetijske dejavnosti na manjših kmetijskih gospodarstvih. Namesto izraza 'polkmet' se zato v strokovni literaturi in kmetijski zakonodaji vse bolj uveljavljata pojma 'mešana kmetija' in 'mešano gospodinjstvo' (Udovč, Kovačič, Kramarič, 2005; Razpotnik Visković, 2012), ki z gospodarskega in agronomskega vidika ustrezneje opisujeta problematiko sodobnih kmetij z dohodki iz več dejavnosti. Mnogo manj sta omenjena pojma uporabna pri socioloških in geografskih raziskavah, ki preučujejo značilnosti življenja in navad ljudi v tovrstnih gospodinjstvih. Za člane takih gospodinjstev se zaradi velikih medsebojnih razlik v načinu dela in preživljanja vsakdana (še) ni uveljavil skupni strokovni izraz, ki bi uspešno nadomestil pojem 'polkmet'.

Člane sodobnih polkmečkih gospodinjstev še vedno povezujejo nekatere skupne značilnosti, ki jih ločijo od načina življenja čistih kmetov. Odvisnost od dohodkov kmetije je tudi danes manjša kot pri čistih kmetih, prav tako jim ostaja možnost vlaganja denarnih sredstev v razvoj kmetije iz nekmetijskih dejavnosti. Večja kmečka opravila se morajo prilagoditi delovnemu času zaposlenih članov. Zaposlitev izven kmetije ima (vedno večji) vpliv na vrednote, vsakdanje izzive in probleme mešanih gospodinjstev, zato bi bilo smiselno za to skupino oblikovati nov skupni pojem in opredelitev. Neodgovorjeno ostaja tudi vprašanje, kaj bi se zgodilo s polkmeti $\mathrm{v}$ primeru izgube zaposlitve izven kmetije. Morda bi se zopet posvetili kmetovanju predvsem s ciljem samooskrbe? 


\section{SKLEP}

Polkmečka struktura že skoraj pol tisočletja vpliva na kulturno pokrajino in družbo v njej (Logar, 2012). Na majhnih kmetijah se je zaradi nje ohranila kmetijska dejavnost, nekoliko upočasnjena sta bila procesa kopičenja lastništva kmetijskih zemljišč $\mathrm{v}$ rokah velikih kmetov ter spreminjanja fiziognomske podobe naselja $\mathrm{v}$ času industrializacije. Imeli so ključno vlogo pri nastanku kratkih oskrbnih verig, saj so med sodelavci v službi našli kupce za pridelke s kmetije. Ker so se na kmetiji oskrbovali s hrano in lesom za ogrevanje, stroške njihovega socialnega in pokojninskega zavarovanja pa je nosil delodajalec, so lahko velik del denarnih dohodkov prihranili in vložili v kmetijo. To jim je omogočilo nenehno posodabljanje kmetije in višji življenjski standard.

Dvojno zaposlitev je spodbujala tudi socialistična družbena ureditev. Njen zaton je polkmete prisilil k spremembi načina življenja in gospodarjenja. Diferenciacija in specializacija gospodarskih funkcij v zaposlitvah izven kmetije kot tudi v kmetijski dejavnosti otežuje kombiniranje dveh zaposlitev. Ker večina polkmetov živi na majhnih kmetijah in se ukvarja s tradicionalnimi kmetijskimi panogami (pridelava krompirja, mlečna živinoreja), je preusmeritev kmetijske dejavnosti v donosnejše panoge, ki je za njihov obstanek bistvena, s finančnega in tehničnega vidika izjemno zahtevna. Na kmetijskih trgih zaradi močne konkurence in uvoženega nizkocenovnega blaga težko najdejo kupce. Soočajo se s pomanjkanjem časa in kapitala, svoje ponudbe ne zmorejo prilagoditi trgu in tržiti pridelkov. Na svoje težave premalo opozarjajo; zaradi medsebojnih sporov je nemalokrat onemogočeno organiziranje medsebojne strokovne pomoči, zadružnih zvez in društev. Tudi kmetijska politika z administrativnimi predpisi ne olajšuje gospodarjenja na kmetijah polkmetov.

Polkmečka struktura se je v Voklem pod vplivom odprtega kmetijskega trga in sodobne družbene ureditve spremenila: del polkmetov je kmetovanje opustil, preostali pa se novim razmeram skušajo prilagoditi. Polkmet vse več časa preživi na delovnem mestu izven kmetije, saj mu je to vse pomembnejše, ker prinaša večjo finančno varnost in boljše možnosti za uspeh kot domača kmetija. Tudi preostali čas ne posveča zgolj kmetovanju, temveč del dneva namenja tudi rekreaciji in prostemu času. Nekateri polkmetje gledajo na kmetijo kot priložnost za dodaten zaslužek, večini pa lastništvo zemlje predstavlja priložnost za samooskrbo in 'zlato rezervo' v primeru Življenjskih kriz.

Preusmeritev kmetijske dejavnosti polkmetov in uskladitev dvojnega življenja je močno odvisna od generacijske sestave gospodinjstev, površine kmetijskih zemljišč ter inovativnosti gospodarjenja kmečkih gospodarjev. Pri ovrednotenju sodobnih razvojnih smeri polkmetov v Voklem smo ugotovili, da njihov način življenja ne ustreza več uveljavljenim opredelitvam, saj se je njihov način življenja močno spremenil in zahteva, da se za to socialno skupino ustvari nov pojem ali pa se nanovo opredeli starega.

Prispevek je rezultat raziskave, ki jo je avtor opravil ob pisanju zaključne seminarske naloge $\mathrm{z}$ naslovom Sodobna vloga polkmetov na primeru Voklega na Oddelku za geografijo Filozofske fakultete Univerze v Ljubljani v študijskem letu 2011/2012. 


\section{Viri in literatura}

Benkovič Krašovec, M., 2006. Centralna naselja na podeželju v Sloveniji. Geografski obzornik, 53, 3, str. 10-18.

Blaznik, P., 1966. Posebnosti starejše agrarne strukture na Dolenjskem. Kronika: časopis za slovensko krajevno zgodovino, 14, 1, str. 1-8.

Geografski terminološki slovar. 2005. Kladnik, D., Lovrenčak, F., Orožen Adamič, M. (ur.). Ljubljana, Založba ZRC, 451 str.

Golc, R., 2012. Podatki o številu oddanih zbirnih vlog za pridobitev kmetijskih subvencij v Voklem v zadnjih desetih letih (osebni vir, 5. 5. 2012). Kranj.

Ilešič, S., 1933. Kmetska naselja na vzhodnem Gorenjskem. Geografski vestnik, 9, str. 3-94.

Kataster stavb. Katastrska občina Voglje. 2012. Ljubljana, Geodetska uprava Republike Slovenije.

Kladnik, D., 1999. Leksikon geografije podeželja. Ljubljana, Inštitut za geografijo, 318 str.

Kladnik, D., 2012. Izrazje o polkmečki strukturi (osebni vir, 2. 7. 2012). Ljubljana.

Klemenčič, M. M., 1970. Spremembe socialno-geografske strukture gospodinjstev kot faktor preobrazbe agrarne pokrajine na primeru naselij Kovor, Voklo, Bašelj in Loka pri Tržiču. Diplomsko delo. Ljubljana, Filozofska fakulteta, Oddelek za geografijo, 81 str.

Klemenčič, M. M., 1974. Socialna in ekonomska struktura mešanih delavsko-kmečkih gospodinjstev na kmečkih gospodarstvih. Geografski vestnik, 46, str. 61-74.

Klemenčič, M. M., Lampič, B., Potočnik Slavič, I., 2008. Življenjska (ne)moč obrobnih podeželskih območij v Sloveniji (GeograFF 3). Ljubljana, Znanstvena založba Filozofske fakultete, Oddelek za geografijo, 149 str.

Klemenčič, V., 1968. Problemi mešane strukture gospodinjstev in kmečkih gospodarstev v Sloveniji. Geografski vestnik, 40, str. 19-52.

Klemenčič, V., 2012. Preučevanje polkmečke strukture v socialni geografiji (osebni vir, 24. 6. 2012). Lucija.

Koblar, A., 1892. Od kod pride ime Voklo (Hülben)? Izvestja Muzejskega društva za Kranjsko, 2, 1, str. 151-152. URL: http://www.dlib.si/?URN=URN:NBN:SI:DOC-BTSPGSTE (Citirano 2. 5. 2012).

Krašovec, S., 1965. K splošnemu vprašanju kmeta-delavca. Ekonomski zbornik, 7, 1, str. $7-19$.

Logar, E., 2012. Sodobna vloga polkmetov na primeru Voklega. Zaključna seminarska naloga. Ljubljana, Filozofska fakulteta, Oddelek za geografijo, 53 str.

Logar, E., 2013. Sodobna vloga polkmetov na primeru Voklega. GEOmix, 19, 2, str. 35-38.

Melik, A., 1959. Slovenija. Knj. 4. Posavska Slovenija. Ljubljana, Slovenska matica, 595 str.

Opis območij z omejenimi možnostmi za kmetijsko dejavnost. V: Program razvoja podeželja Republike Slovenije 2007-2013. 2007. Ljubljana, Ministrstvo za kmetijstvo, gozdarstvo in prehrano, 15 str. URL: http://www.mko.gov.si/fileadmin/mko.gov.si/pageuploads/podrocja/Program_razvoja_podezelja/priloga_3.pdf (Citirano 14. 5. 2012).

Popis 2002. Statistični urad Republike Slovenije. URL: http://www.stat.si/popis2002/si/ default.htm (Citirano 2. 5. 2012). 
Popis kmetijskih gospodarstev 2000. 2002. Ljubljana, Statistični urad Republike Slovenije, 256 str. URL: http://www.stat.si/publikacije/pub_rr777-02.asp (Citirano 21. 11. 2013).

Popis kmetijstva 2010. 2012. Ljubljana, Statistični urad Republike Slovenije. URL: http:// pxweb.stat.si/pxweb/Database/Kmetijstvo_2010/Kmetijstvo_2010.asp (Citirano 21. 11. 2013).

Popis prebivalstva, gospodinjstev in stanovanj v SR Sloveniji 31. 3. 1981. Zaposleni po področjih dejavnosti in po naseljih. 1984. Ljubljana, Zavod SR Slovenije za statistiko, 124 str.

Popis prebivalstva, gospodinjstev, stanovanj in kmečkih gospodarstev v Republiki Sloveniji v letu 1991. 1994. Ljubljana, Zavod RS za statistiko, 395 str.

Popis stanovništva 1961. Aktivnost i delatnost. Rezultati za naselja. 1965. Beograd, Savezni zavod za statistiku, 368 str.

Popis stanovništva i stanova 1971. 1974. Beograd, Savezni zavod za statistiku, 120 str.

Prebivalstvo LR Slovenije po proizvodnih panogah. Popis prebivalstva 1953. 1954. Ljubljana, Zavod za statistiko in evidenco LR Slovenije, 72 str.

Potočnik Slavič, I., 2010. Endogeni razvojni potenciali slovenskega podeželja (GeograFF 7). Ljubljana, Znanstvena založba Filozofske fakultete, Oddelek za geografijo, 131 str.

Program razvoja podeželja Republike Slovenije za obdobje 2007-2013 (6. sprememba). 2007. Ljubljana, Ministrstvo za kmetijstvo in okolje. URL: http://www.mko. gov.si/fileadmin/mko.gov.si/pageuploads/podrocja/Program_razvoja_podezelja/ prp_2007_2013_6_sprememba_po_pripombah.pdf(Citirano 14. 5. 2013).

Razpotnik Visković, N., 2012. Vloga mešanih kmetij v gospodarski, okoljski in prostorski preobrazbi obmestij. Doktorska disertacija. Ljubljana, Fakulteta za gradbeništvo in geodezijo, 182 str.

Razvojni program Občine Šenčur za obdobje 2004-2013. 2004. URL: http://www.sencur. si/assets/files/razvojni_program.pdf(Citirano 14. 7. 2013).

Rogelj, M., 2006. Zgodovinski utrinki razvoja krajev v občini Šenčur. V: Kadivec, M. (ur.).

Pod Jurijevim klobukom. Zbornik Občine Šenčur 2006. Šenčur, str. 119-137.

Ruppert, K., Schaffer, F., Maier, J., Paesler, R., 1981. Socijalna geografija. Zagreb, Školska knjiga, 159 str.

Udovč, A., Kovačič, M., Kramarič, F., 2005. Socio-ekonomski tipi kmetij po podatkih Popisa kmetijskih gospodarstev v letu 2000. URL: www.stat.si/doc/sosvet/sosvet_08/ sos08 s345-2005.doc (Citirano 5. 6. 2012).

Woods, $\bar{M}$., 2005. Rural geography. London, Sage Publications, 336 str.

\section{CONTEMPORARY DEVELOPMENTALTENDENCIES OF PART-TIME FARMERS:THE CASE STUDY OF VOKLO}

\section{Summary}

For almost a half of the millennium the structure of part-time farmers has been affecting cultural landscape and society. While agricultural activity has been sustained on smaller farms, two other processes have been slowed down. First is the concentration of land in the hands of big, full-time farmers, and the second are physiognomic changes 
of the village in the period of industrialisation. The part-time farmers had a crucial role in subsistence food provision, because the farmers found the consumers for their agricultural products in their employment milieu outside the agricultural holdings. Part-time farmers have been supplied with food and wood for heating from their land, while their expenses on social and retirement insurance were paid by their employer. All these factors have enabled the part-time farmers to invest the majority of their life savings into the farm. This has resulted in constant updating of the farm and in higher standard of living for members of agricultural holdings.

Double employment was encouraged also by the socialist system. After its decay, part-time farmers had been forced to change their way of life and manage the work on their farms differently. Differentiation and specialisation of economic functions in both areas of employment, in agricultural holdings as in other non-farm businesses, has made the combination of the employment more challenging. The diversification of agriculture into other agricultural activities is crucial from the financial and technical point of view and extremely demanding. However, they are able to do this because most of part-time farmers lived on the smaller farms with potato production and dairy farming. It is very hard to find customers now, because of strong competition and imported goods at low prices. Part-time farmers are facing the scarcity of time and capital, and aren't able to adjust their offer to the market and to market their products intensively. They rarely talk about their problems. Due to different disputes between various part-time farmers, their common activities mostly disappeared. And then there is also the agricultural policy with administrative regulations which brings several additional constraints for small part-time farmers.

The structure of part-time farmers in Voklo has been under the influence of open agricultural market and the contemporary socio-economic system. A part of part-time farmers has abandoned their agricultural activities, the rest of them have difficulties to adjust to the contemporary situation. A part-time farmer spends more and more time working outside the agricultural holding because this off-farm employment is more important. Similarly, (s)he doesn't spend all his (her) day working on his (her) farm, but (s)he rather dedicates his (her) time to outdoor activities and recreation. Some part-time farmers see their farm as an additional source of income, but most of them evaluate their farm as an opportunity for self-subsistence and as a reserve for the possible time of crisis.

Diversion of agricultural activities for part-time farmers and coordination of the double life immensely depends on the age structure of the households, on the amount of agricultural land and on the innovativeness of landowners. When one has to evaluate the contemporary role of the part-time farmers in Voklo, one has to know that their life style does not correspond to the established definitions. The reason for this is in their life style that has changed greatly in the last 20 years, there should be the evolution of a new expression for such a social group or the re-definition of the existing one.

(Translated by Rok Škrlec) 